University of Nebraska - Lincoln

DigitalCommons@University of Nebraska - Lincoln

\title{
Geochemical Controls on Contaminant Uranium in Vadose Hanford Formation Sediments at the 200 Area and 300 Area, Hanford Site, Washington
}

\author{
James Mckinley \\ Pacific Northwest National Laboratory, james.mckinley@pnl.gov \\ John M. Zachara \\ Pacific Northwest National Laboratory, john.zachara@pnl.gov \\ Jiamin Wan \\ Lawrence Berkeley Nation Laboratory \\ David McCready \\ Pacific Northwest National Laboratory \\ Steven M. Heald \\ Argonne National Laboratory
}

Follow this and additional works at: https://digitalcommons.unl.edu/usdoepub

Part of the Bioresource and Agricultural Engineering Commons

\footnotetext{
Mckinley, James; Zachara, John M.; Wan, Jiamin; McCready, David; and Heald, Steven M., "Geochemical Controls on Contaminant Uranium in Vadose Hanford Formation Sediments at the 200 Area and 300 Area, Hanford Site, Washington" (2007). US Department of Energy Publications. 300.

https://digitalcommons.unl.edu/usdoepub/300

This Article is brought to you for free and open access by the U.S. Department of Energy at DigitalCommons@University of Nebraska - Lincoln. It has been accepted for inclusion in US Department of Energy Publications by an authorized administrator of DigitalCommons@University of Nebraska - Lincoln.
} 


Geochemical Controls on Contaminant Uranium
in Vadose Hanford Formation Sediments at the 200
Area and 300 Area, Hanford Site, Washington
James P. McKinley, ${ }^{*}$ John M. Zachara, Jiamin Wan, David E. McCready,
and Steven M. Heald
Long-term historic spills of uranium at the 300 Area fuel fabrication site (58,000 kg of disposed uranium over 32 yr) and at the
200 East Area BX tank farm (7000 kg of spilled uranium in one event), both within the Hanford formation in the Hanford Site,
Washington State, were investigated by subsurface sampling and subsequent microscale investigations of excavated samples. The
200 Area sediments contained uranyl silicate mineralization (sodium boltwoodite) in restrictive microfractures in granitic clasts,
in the vadose zone over a narrow range in depth. Well logging and column experiments indicated that tank wastes migrated
deeper than observed in core samples. The 300 Area sediments included metatorbernite and uranium at low concentrations
associated with detrital aluminosilicates, along with other mineral phases that could accommodate uranyl, such as uranophane
and calcium carbonate. The association of contaminant uranyl with Hanford formation sediments provided a persistent source
of uranium to groundwater. The results of both studies suggest that the formation of secondary solid uranyl-bearing phases
influences the subsequent release of uranium to the environment and that our understanding of these processes and individual
waste sites is incomplete.

ABBREVIATIONS: bgs, below ground surface; EMP, electron microprobe; SEM, scanning electron microscope; TEM, transmission electron microscopy; XMP, X-ray microprobe; XRD, X-ray diffraction.

$\mathrm{F}$ rom 1943 until 1989, the Hanford Site in Washington State produced plutonium for weapons applications. The Hanford Site occupies approximately $1500 \mathrm{~km}^{2}$ in an arid environment, bounded by a broad bight of the Columbia River to the east and by the 1000-m Rattlesnake Mountain to the west. Fuel fabrication occurred at the site's southern extremity (300 Area); fuel was irradiated near the Columbia River to the north (100 Areas); and the rods were processed in chemical facilities on the site's central plateau (200 Area). Each of the manufacturing components had a characteristic waste stream or streams, and while some streams were disposed directly onto the ground surface, other streams were retained for long-term storage or isolation. Materials research and fabrication at the 300 Area generated wastes that were sluiced into process ponds (Fig. 1), constructed and maintained to avoid contamination of the nearby Columbia

J.P. McKinley, J.M. Zachara, and D.E. McCready, Pacific Northwest National Lab., Richland, WA 99354; J. Wan, Lawrence Berkeley Nation Lab., Berkeley, CA 94720; S.M. Heald, Argonne National Lab., Argonne, IL 60439. Received 20 Dec. 2006. *Corresponding author (james.mckinley@pnl.gov).

Vadose Zone J. 6:1004-1017

doi:10.2136/vzj2006.0184

(C) Soil Science Society of America

677 S. Segoe Rd. Madison, WI 53711 USA.

All rights reserved. No part of this periodical may be reproduced or transmitted in any form or by any means, electronic or mechanical, including photocopying, recording, or any information storage and retrieval system, without permission in writing from the publisher.
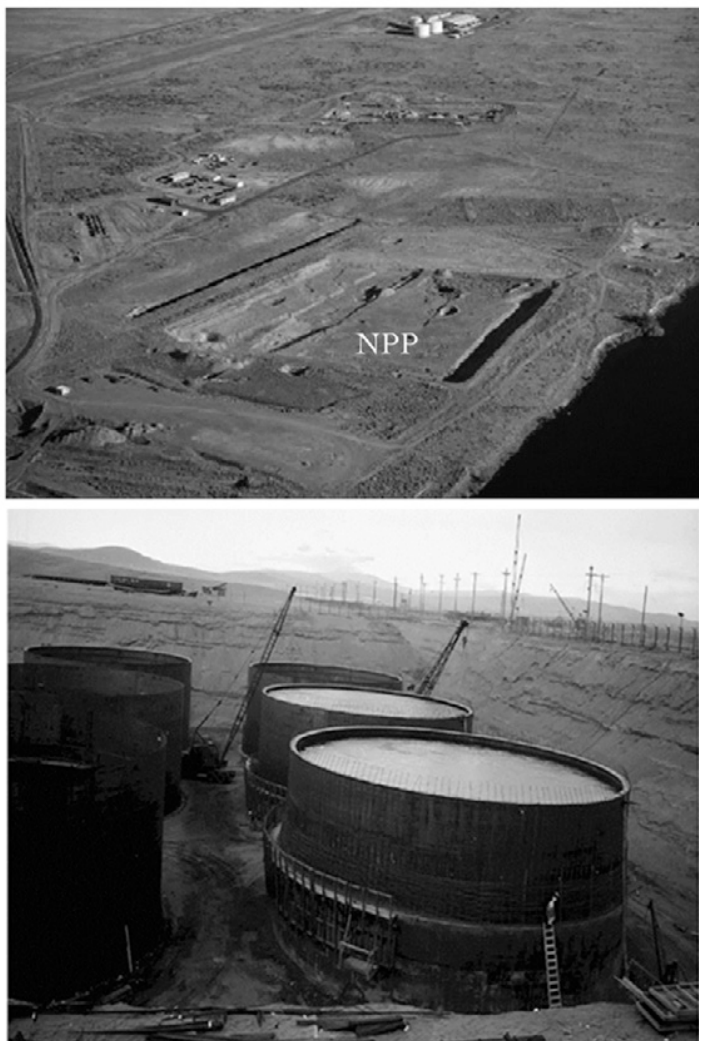

FIG. 1. Upper: Arial photograph of the 300 Area North Process Pond (NPP), in 2003, after excavation of the residual pond wastes. Samples described here were removed from the site after this photo was taken. Lower: Photograph of the 200 East Area BX tank farm under construction, 1944. 
River. The ponds received constant and intermittent releases of a broad variety in composition and volume, including caustic alkaline and acidic fluids and slurries containing uranium, aluminum, and copper. After irradiation, the chemical processing steps in the 200 Area included dissolution of irradiated fuel rods and subsequent industrial-scale chemical manipulations to form distinct compositional streams that were managed to extract useful materials and to isolate wastes. The storage of chemical process intermediates and the disposal of unwanted wastes presented (and continues to present) a significant challenge. During the years of plutonium production, highly radioactive and hazardous wastes were disposed in underground tanks (Fig. 1), which were initially of single-wall construction.

The unintended release of uranium and other wastes to the environment produced contaminated zones in the vadose sediments. The information presented here results from investigations of uranium wastes in the vadose zone that were emplaced by two distinct contaminant events: (i) a historic, episodic leak of alkaline uranium wastes to the thick and deep 200 East Area vadose zone, and (ii) the long-term seepage of acidic or neutral uranium wastes to the thin and shallow 300 Area vadose zone. Both released uranium into the same surficial sedimentary deposit, and each represents the source or potential source of uranium to groundwater. The mobility of uranium is a complex function of the chemical and physical properties and the geological and lithological variations in the subsurface. The present-day geochemical behavior of the wastes appears to be controlled by the composition and morphologic character of the secondary waste-bearing solid phases, which in turn result from the composition and reactivity of the original aqueous waste, which migrated through the vadose environment. The results of these investigations also illustrate the uncertainties and difficulties in understanding the geochemical factors controlling potential environmental hazards of long-resident contaminants in the vadose regime.

Uranium is a ubiquitous component of contaminants on USDOE lands (Riley and Zachara, 1992), and in similar sites worldwide, resulting from activities within the Nuclear Weapons complex for the production of enriched uranium and plutonium. Due to the expense and difficulty of remediation efforts for uranium, numerous basic and applied studies of uranium mobility have been undertaken in the USA and elsewhere, and much about its geochemical behavior is known.

Uranium occurs in two predominant oxidation states, $\mathrm{U}(\mathrm{IV})$ and $\mathrm{U}(\mathrm{VI})$. Most uranium deposits consist of solids of $\mathrm{U}(\mathrm{IV})$, which is insoluble under most environmental conditions (Grenthe et al., 1992). The formation of uranium deposits and the analogous immobilization of uranium through microbial reduction processes have been a focus of much environmental research (Anderson et al., 1989a, 1989b, 2003; Barnes and Cochran, 1993; Finch and Murakami, 1999; Finneran et al., 2002; Idiz et al., 1986; Langmuir, 1978; Leventhal and Dawn, 1986; Lovley, 1993; Lovley et al., 1991; Michalsen et al., 2006; Plant et al., 1999; Suzuki et al., 2003; Zielinski and Meier, 1988). The oxidized form of uranium, U(VI), in the form of the uranyl ion, $\mathrm{UO}_{2}{ }^{2+}$, is relatively soluble and is thus of concern as a mobile contaminant in saturated and unsaturated natural systems. In solution above $\mathrm{pH} 5$, the uranyl ion hydrolyzes, forming aqueous hydroxide complexes and polymers of uranyl hydroxide
(Baes and Mesmer, 1976; Finch and Murakami, 1999; Grenthe et al., 1992). The hydroxy complexes are relatively weak, and in most groundwaters, uranyl occurs as stronger complexes with dissolved carbonate (Langmuir, 1978). Uranyl hydroxides may precipitate where the more soluble complexes are absent; otherwise uranyl carbonates (or sulfates) precipitate from the uranylcomplexant solution, or, where dissolved silica or phosphate are available, the relatively insoluble silicate or phosphate minerals precipitate. Evolving groundwater composition can control the saturation conditions and precipitation of uranyl minerals. In undersaturated solutions, sorption influences uranyl ion mobility. The uranyl ion has been shown to interact strongly with common and abundant mineral components in natural systems, including metal oxides, aluminosilicates, and carbonates (Barnes and Cochran, 1993; Hsi and Langmuir, 1985; Idiz et al., 1986; Lieser et al., 1992; Maya, 1982; McKinley et al., 1995; Mikami et al., 1983; Morris et al., 1994; Prikryl et al., 2001; Zachara and McKinley, 1993). Generally, uranyl is complexed by negative fixed-charge or amphoteric sites on mineral surfaces. Aqueous complexation reactions, such as those with carbonate or sulfate species, compete with surfaces for dissolved uranyl and may limit the extent of the sorption reaction. The retardation and immobilization of uranium in a reactive mobile system is thus a function of the interplay between oxidationreduction, sorption, and precipitation, affected by reactants and reactions along a groundwater flow path. We expected the advected uranyl in the migrating contaminant plumes to interact with solid surfaces either through sorption or precipitation, as suggested by previous work (Catalano et al., 2004, 2006; Liu et al., 2004) and specifically looked for uranium in sorbed and precipitated forms.

The physical setting of the contaminated sites described here is one in which geology controls the flow of groundwater and the thickness of the vadose zone. The Hanford Site is underlain by three lithological units distinct in age and depositional environment. The broadest and stratigraphically lowest are the regional, folded Miocene Columbia River Flood Basalts (Hooper, 1982), defining the anticlinal topographic high to the west of the site (Rattlesnake Mountain) and the structural basin (the Pasco Basin) within which the site is located (Reidel et al., 1994). These are overlain by the Miocene-Piocene fluvio-lacustrine sediments of the Ringold Formation (Bjornstad, 1990; McKinley et al., 1997), lying without deformation and incised by erosion. The uppermost formation is the Quaternary Hanford formation (Bjornstad et al., 1987). Both of the contaminant uranium occurrences described here were within the Hanford formation, which was deposited by periodic catastrophic ice-age floods, and consisting of unconsolidated sediment ranging from gravelly to sandy-silty lithologies. The water table slopes from Rattlesnake Mountain where springs are present, eastward toward the Columbia River where it is coincident with the river shore. The vadose zone at the central plateau (200 Area) between the regional uplands and the river is as much as 100-m thick. Chemical processing facilities were constructed on the plateau. At the fuels fabrication site (300 Area at the site's southern extreme), the shallow water table is beneath a vadose zone that is at most less than 10-m thick (Bjornstad, 1990; Zachara et al., 2005). 


\section{Materials and Methods}

\section{Area Spill}

The BX tank farm, in the central plateau's 200 East Area, was constructed from 1946 to 1947 and was used to store and separate solid waste sludges and liquids (Williams, 1999). During the movement of sludge by gravity flow from one tank to another in 1951, an intertank pipeline ruptured and about $350,000 \mathrm{~L}$ of waste were released to ground, including more than $7000 \mathrm{~kg}$ of uranium in an alkaline matrix of sodium carbonate, nitrate, phosphate, and sulfate (Jones et al., 2001). The nature of the vadose zone contaminant plume was investigated by core drilling (Serne et al., 2002b). Cores were collected using driven split spoons, avoiding drilling-related contamination, and steel casing was driven as the drilling progressed. (The "split spoon" is a steel cylinder, split into lengthwise halves and fitted with a hardened collar at its leading edge.) To reach a depth of $80 \mathrm{~m}$ below ground surface (bgs; $2.3 \mathrm{~m}$ below the water table), the borehole was installed in three stages in which the drive barrel diameter was decreased with depth to form a nested or telescoped sequence of borehole diameters. Thirty-five split spoon samples were collected at intervals of approximately $3 \mathrm{~m}$ by driving the split spoon sampler ahead of the casing into undisturbed sediment. Stainless-steel split spoon liners were removed from the samplers at the ground surface, sealed in plastic and transported to the laboratory at $4^{\circ} \mathrm{C}$. (The investigated plume originated from a tank within the BX tank farm, which was designated 241-BX-102; Fig. 2). Gamma and neutron spectra were collected through the casing, and the in situ radionuclide activity and relative moisture content were calculated from well logs (McCain, 2006).

Sediments removed from split spoon liners were characterized according to their lithologic properties and were processed to determine selected compositional qualities. Visual estimates of grain-size distributions were tabulated for the construction of a lithologic-stratigraphic column for representational purposes. Moisture contents were determined gravimetrically (ASTM, 1998); a 15- to 70-g subsample was placed in a tared container, weighed, and dried at $105^{\circ} \mathrm{C}$ to constant weight, and the water content was calculated as the percentage change in weight. Sediments were sieved to provide a uniform $<2-\mathrm{mm}$ size fraction for all other tests.

The sediments were too dry to effectively extract pore waters, so a 1:1 extraction using deionized water was used to provide analyte for wet-chemical measurements. Water equivalent in weight to the dry mass of 60 - to $80-\mathrm{g}$ samples was added to the field moist samples in screw-top jars, which were sealed and placed on an orbital shaker for $1 \mathrm{~h}$. The samples were allowed to settle, were decanted, and were separated into an unfiltered aliquot for $\mathrm{pH}$, and a filtered $(0.45-\mu \mathrm{m})$ aliquot for cation, anion,

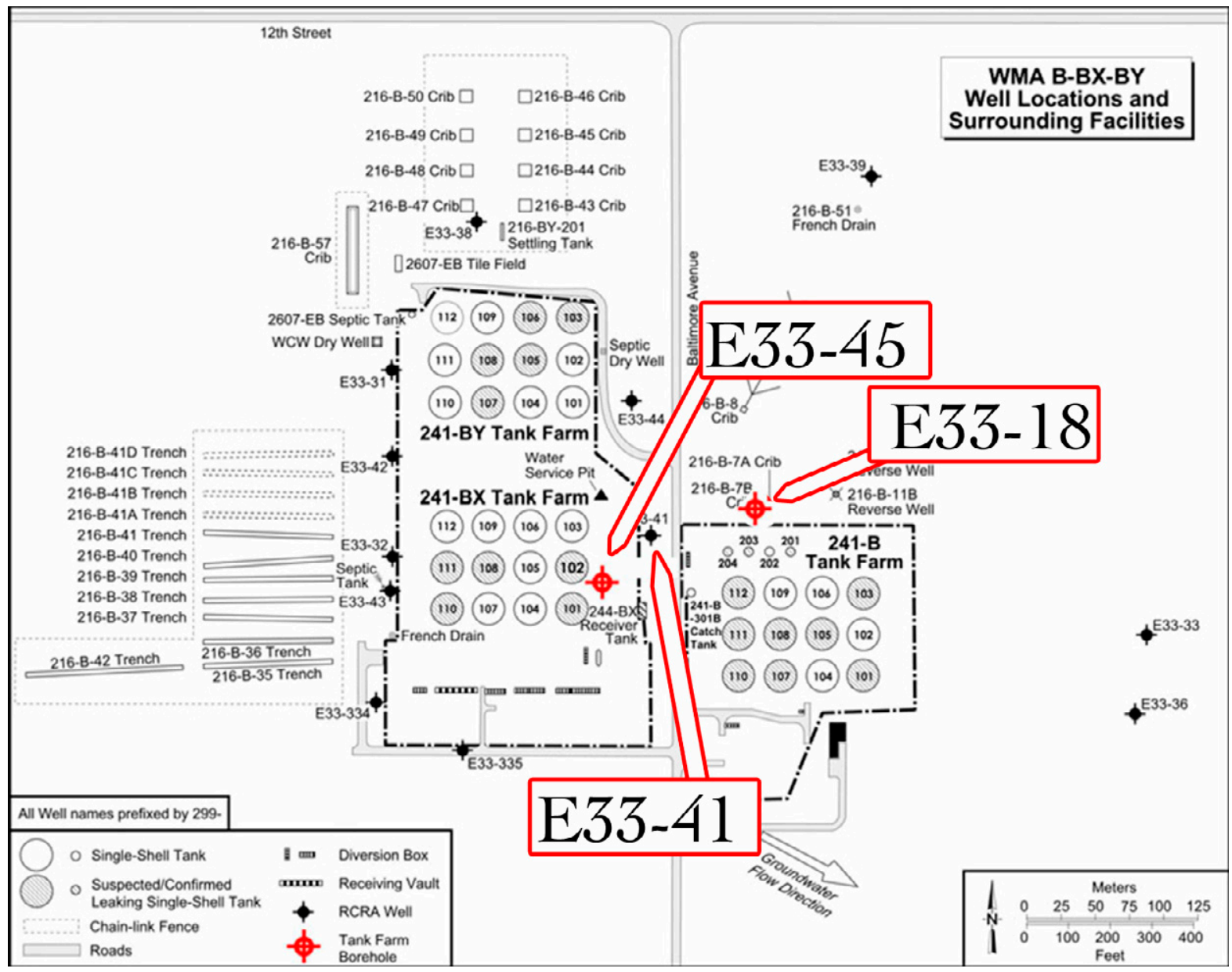

FIG. 2. Layout of the completed B-BX-BY tank farm. The 1951 spill occurred at tank BX-102. Locations of boreholes 299-E33-45, 299-E33-41, and 299-E33-18 are indicated. 
and carbon analyses. The aqueous analytical results were corrected by assuming that only dilution of pore water occurred during the extraction process, to provide an estimation of the pore water composition. A small subset of duplicate samples was ultracentrifuged at several thousand $g$ for $8 \mathrm{~h}$, to express pore water, which was analyzed for compositional parameters, including $\mathrm{pH}$, inorganic carbon, cations, and anions. Results from the limited number of direct pore water measurements (not shown) were different from the extracted and calculated compositions due to reaction between the sediment and the deionized water. The influence of cation exchange and carbonate solubility on laboratory leachate compositions has been discussed elsewhere in some detail (McKinley et al., 2005). The extractions nonetheless provided a good estimate of the relative impact of waste solutions on the vadose zone and of the spatial distributions of waste components.

Experimental evaluations of waste-sediment interaction were made using uncontaminated Hanford formation sediment packed into experimental columns (Wan, unpublished data, 2007). The metal waste solution for these tests was synthesized based on the historical recipe (Jones et al., 2001). The metal waste solution contained $0.11 \mathrm{M} \mathrm{U}(\mathrm{VI}), 3.6 \mathrm{M} \mathrm{Na}^{+}, 0.8 \mathrm{M}$ $\mathrm{CO}_{3}{ }^{2-}, 0.34 \mathrm{M} \mathrm{PO}_{4}^{3-}, 0.24$ and $\mathrm{M} \mathrm{SO}_{4}{ }^{2-}$ and had a $\mathrm{pH}$ of 10.4. The waste solution was injected into columns at $70^{\circ} \mathrm{C}$ at

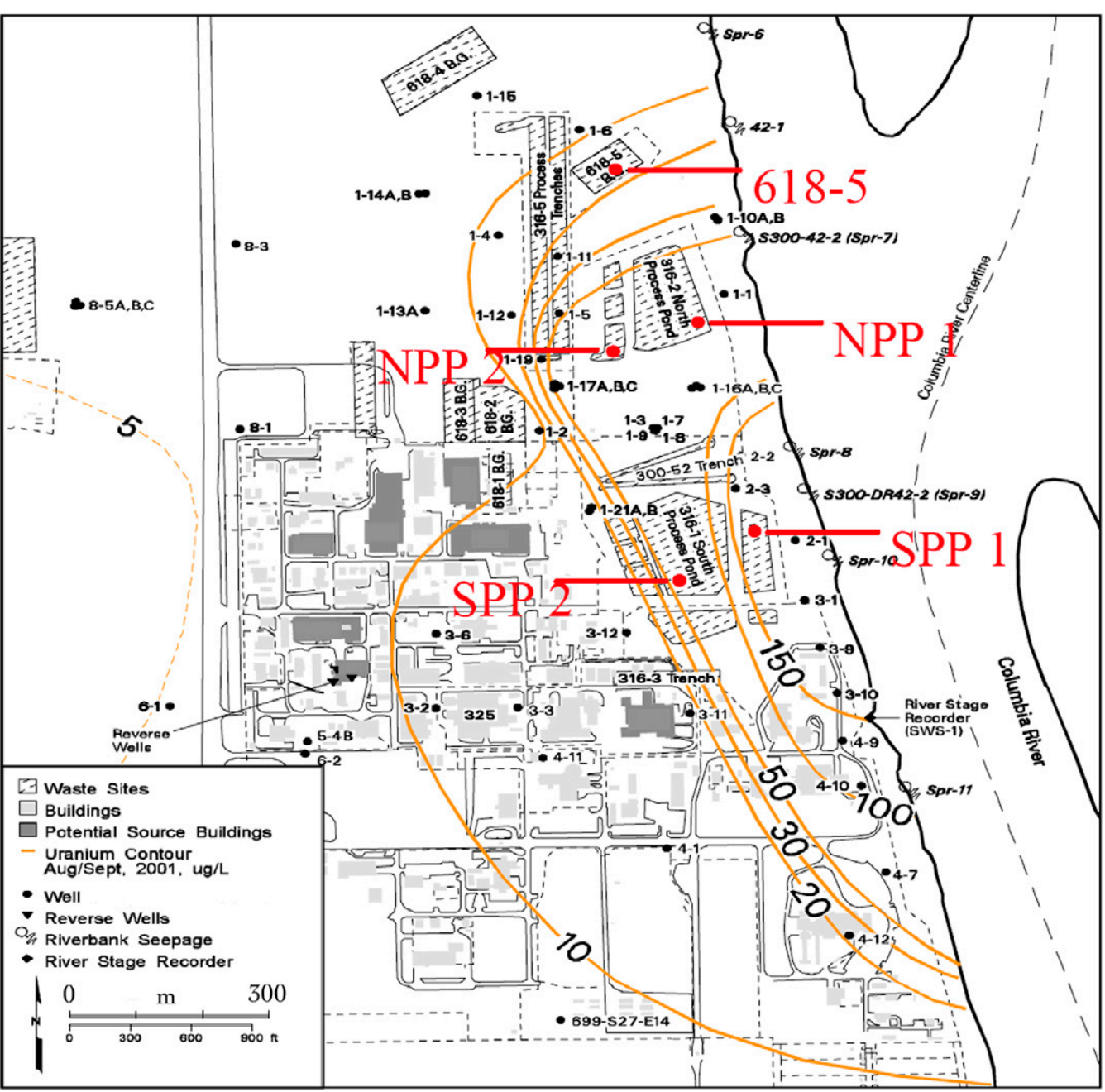

FIG. 3. Uranium contaminant plume concentrations in the Hanford Site 300 Area. The excavated process ponds were located near the river shore. The North Process Pond (NPP) sample locations are indicated. varied flow rates. In each column, flow was stopped just before the plume front was calculated to reach the opposite end of the column; then the column was sectioned and the pore liquid was extracted from each segment of the column.

\section{Area Spill}

The North and South 300 Area Process Ponds (in the 300-FF-5 Operable Unit) received basic sodium aluminate and acidic $\mathrm{U}(\mathrm{VI})-\mathrm{Cu}(\mathrm{II})$ waste streams from the dissolution of nuclear fuel and fuel rod cladding from 1943 to 1975. The two ponds received approximately $58,000 \mathrm{~kg}$ of $\mathrm{U}, 238,000 \mathrm{~kg}$ of $\mathrm{Cu}, 1,156,00 \mathrm{~kg}^{\circ} \mathrm{F}^{-}, 243,000 \mathrm{~kg}$ of $\mathrm{NO}_{3}^{-}$, and large amounts of $\mathrm{Al}$ as $\mathrm{Al}(\mathrm{OH})_{4}^{-}$. The $\mathrm{pH}$ of the pond water was temporally variable, ranging from 1.8 to 11.4 . Sodium hydroxide was frequently added when the $\mathrm{pH}$ was acidic to minimize leaching of $\mathrm{Cu}$ and $\mathrm{U}$ through the vadose zone into the underlying unconfined aquifer and onto the Columbia River. However, waste disposal resulted in a groundwater plume of U(VI) (Fig. 3) that persists today.

Contaminated sediments were collected at two different times from the Hanford 300 Area Process Pond complex. The first sampling campaign occurred in the early 1990s when dry, contaminated sediments were collected directly from the base of the drained North Process Pond in two locations (NP 1 and NP 4). Samples were collected over depth at both locations; we include a single image (see "Results and Discussion," below) for a reference sample from the first sampling, specifically, NP 4-1 (0.3-m [1-ft] depth). In 1996, in accordance with recommendations of the USEPA (1996), 640,000 tons of contaminated sediment were removed from the pond bottoms. Several additional meters of contaminated sediment were removed in 2001-2002 to reduce $\mathrm{U}(\mathrm{VI})$ contaminant levels further, to concentrations considered protective of groundwater. In 2003 additional samples were collected at and below the secondary surface of the 2001-2002 remediation effort (Fig. 1). A large excavator was used to expose a pit in the current land surface (NPP 2 in Fig. 3), through the vadose zone to groundwater at the west side of the North Process Pond. Sediment samples were collected over depth within this pit. Two sediments from this 2003 sampling were selected for this study: NPP 2-0.5 (0.15-m [0.5-ft] depth), NPP 2-4 (1.2-m [4-ft] depth). 
An additional, similar collection produced an analogous "deep" sample, NPP 1-16 (4.9-m [16-ft] depth). All listed depth values are with respect to the ground surface at the time of sampling; because the thickness of sediment removed during remediation was not known accurately, a precise depth relationship could not be established between the NP and NPP samples, although all NPP samples were from several meters below the NP samples. The sediments were dry-sieved to yield a $<2.0-\mathrm{mm}$ size fraction for more detailed chemical and mineralogical study of the reactive components.

\section{Instrumental Analysis}

Dissolved cation concentrations were determined using inductively coupled plasma, optical emission, or mass spectrometer instruments, with appropriate dilutions. Anion concentrations were determined using ion chromatography, and inorganic carbon was determined using a Shimadzu (Columbia, MD) carbon analyzer (not shown). Acidity was measured on the unfiltered 1:1 aliquot, using a buffer calibrated $\mathrm{pH}$ electrode and meter (not shown).

Total elemental composition was determined by energydispersive X-ray fluorescence spectroscopy (0810A system, Kevex, Scotts Valley, CA). The inorganic carbon content of the sediments was determined using a Shimadzu carbon analyzer, model TOC-V, SSM-5000A. Powder X-ray diffraction (XRD) measurements were performed with an X'Pert X-ray diffractometer (Philips, Almelo, the Netherlands) operating in a step scan mode, using $\mathrm{Cu} \mathrm{K} \alpha$ radiation and a graphite monochromator. Sediments from the Hanford formation can vary in texture, but the XRD mineralogic composition within specific size fractions (such as sand, silt, or clay) tends to be almost identical in all samples analyzed (Zachara et al., 2005).

The NPP subsamples were imbedded in epoxy, wafered using a diamond saw, and prepared as $100-\mu \mathrm{m}$ thin sections on fused quartz slides. Measurements were made at the Argonne National Laboratory Advanced Photon Source on the Pacific Northwest Consortium Collaborative Access Team beamline (Heald et al., 1999). The primary X-ray beam was focused using Kirkpatrick-Baez mirrors to a 6 - to $7-\mu \mathrm{m}$ diameter on the sample surface. The sample was oriented in a precision-translation stage at $45^{\circ}$ to the X-ray beam, and the detectors were oriented normal to the beam. Uranium maps were obtained by monitoring the $\mathrm{U} M \alpha$ fluorescence line using energy dispersive and wavelength dispersive spectrometers. Other elements were monitored and used to aid registration with scanning electron microscope (SEM) images. The detection limit was approximately $1 \mu \mathrm{g} \mathrm{g}^{-1}$ for all elements, equivalent to approximately $10^{9}$ element-ofinterest atoms within the beam "spot." Fluorescence X-ray intensities were normalized to the ion chamber current generated by the primary X-ray beam at a flux of about $5 \times 10^{15} \mathrm{~lx}$ $\mathrm{s}^{-1}$. Scanning electron microscope and X-ray microprobe (XMP) images were superimposed using Adobe PhotoShop (San Jose, CA). Thin sections were carbon coated and examined using a model 6340 fEM and model 8200 electron microprobe (EMP) (JEOL, Peabody, MA). For EMP elemental abundance maps, wavelength spectrometers were calibrated against commercial standards. Fracture areas including uranyl silicates were prepared for transmission The fracture surface, exposed on a polished thin section, was stabilized through the focused ion beam deposition of a Pt layer electron microscopy (TEM) using a 200TEM (FEI, Portland, OR) focused ion beam system. An approximately $2-x$ $20-\mu \mathrm{m}$ pillar of material was milled free from the bulk using the focused Ga ion beam. The pillar was lifted and Pt-welded onto a $\mathrm{Cu}$-ring TEM half-grid. Once secured to the TEM grid, the Ptsupported fracture face and fracture fill were milled to a slab of uniform approximately $200 \mathrm{~nm}$ thickness for subsequent TEM analysis. For imaging, energy dispersive X-ray spectroscopy, and selected-area electron diffraction analysis, we used a Tecnai F30 TEM (FEI, Portland, OR), operating at $300 \mathrm{KeV}$ and equipped with a Gatan (Pleasanton, CA) imaging filter. This methodology has been described in more detail elsewhere (Heaney et al., 2001; Lomness et al., 2001; Prenitzer et al., 1998).

\section{Results and Discussion}

The uranium in all of the vadose samples was hexavalent, coordinated as the uranyl ion $\left(\mathrm{UO}_{2}{ }^{2+}\right)$, confirmed by X-ray absorption spectroscopic measurements (not shown), described in detail elsewhere (Catalano et al., 2004, 2006; Wang et al., 2004).

\section{Area Leak}

Investigations of contaminated sediments removed from the vadose zone plume, careful analysis of groundwater isotopic variations, spectral gamma logging of the vadose zone within and adjacent to the B-BX-BY tank farm, and experimentation with simulated waste solutions and Hanford formation sediments were used to examine the emplacement and mobility of uranium emplaced by the 1951 spill as well as the origin of nearby uranium within the vadose zone. As discussed below, the interpretation of the data raised questions requiring further sampling and research to fully and unambiguously describe the uranium contamination near the B-BX-BY tank farm. The results illustrate the difficulty of investigating contaminants within the deep vadose environment and the tenuous nature of interpretations made from disparate and incomplete data.

The results for core sampling and analysis are summarized in Fig. 4; more detailed results were presented elsewhere (Serne et al., 2002b). The Hanford formation at the 299-E33-45 location consisted of gravelly and sandy intervals broken infrequently by finer-grained, less-conductive sediments. The fine-grained sediments retained moisture at levels greater than $10 \% \mathrm{w} / \mathrm{w}$, but the vadose sediments generally included moisture at less than $10 \% \mathrm{w} / \mathrm{w}$, consistent with uncontaminated, arid Hanford Site environments (Serne et al., 2002a). Just above the water table the borehole encountered a fine-grained interval designated the Hanford Plio-Pleistocene unit, which included silty sediments containing elevated moisture contents and a thin perched water zone. Uranium concentrations defined a lobe of contaminated sediment at depths between (33 and $44 \mathrm{~m}$ (110-145 ft) bgs, and total gamma logs were consistent with measurements on core samples except within the Plio-Pleistocene interval, where an unexplained small increase in gamma activity was observed. Within this interval, however, direct measurements of core samples found no detectible uranium.

Electron microscopy analysis of the contaminated sediment showed that the contaminant uranium occurred within microfractures in a subset of the overall clastic subsurface sediment, 
specifically, within granitic lithic fragments rich in plagioclase and potassium feldspar (Fig. 5). Spectroscopic and Xray diffraction studies of the bulk sediments showed that the uranium was hexavalent and that the uranyl-bearing mineral was a silicate, likely sodium boltwoodite (Catalano et al., 2004). In fractures, SEM imaging revealed that the uranyl mineralization defined separated uranyl silicate florettes, associated primarily with plagioclase feldspar (Fig. 5a and 5b). Excavation and preparation of an electron-transparent slab of fracture fill for imaging in TEM (Fig. 5c) showed the spatial relationship across the fractures of individual florettes to the plagioclase substrate and the in situ development of minor aluminosilicate secondary mineralization. The florettes were composed of uranyl silicate, in nanocrystalline form with single crystal domains of approximately $5 \mathrm{~nm}$ across (Fig. 5d). Electron diffraction analysis was consistent with the identification of the secondary mineral as sodium boltwoodite (not shown).

The unusual morphology and limitations on occurrence and abundance of uranyl silicates within the vadose sediments beneath the BX tank farm had interesting implications for the behavior of these waste components during future incursions of aqueous solutions from the surface and required some understanding of waste-sediment interaction responsible for emplacement. The mode of emplacement must have included advection or diffusion of uranyl into the fracture space, since the silicate within the fractures represented more uranium than was present as a solute in the equivalent waste solution volume. A conceptual model for the emplacement of uranyl silicates (McKinley et al., 2006) suggested that the silica-poor waste solution migrated into the vadose zone and interacted initially by mixing with resident pore waters in microfractures, which contained silica in equilibrium with enclosing feldspars. Diffusion of uranyl into the fracture space caused local supersaturation with respect to sodium boltwoodite, and random nucleation promoted the precipitation and growth of microflorettes. Silicate dissolution within the fractures to supply silica, and uranyl diffusion along the precipi- tation-imposed concentration gradient to supply solution uranyl, sustained the precipitation and growth of the sodium boltwoodite within the fractures. This model was tested numerically, indicating that the precipitation-dissolution-diffusion process could explain the occurrence of uranium contamination within microfractures (McKinley et al., 2006). The model was bounded by experimental measurements of diffusion constants, mineral identification by TEM analysis, published solubility constants, and fracture dimensions identified by scanning electron microscopy. The migration and precipitation of uranyl silicate was initiated and rate-limited by diffusion-controlled microfracture solution saturation with respect to sodium boltwoodite.

The microfracture mode of occurrence for uranyl silicates was used also to evaluate the potential for uranium release from contaminated sediments in contact with electrolyte solutions. 


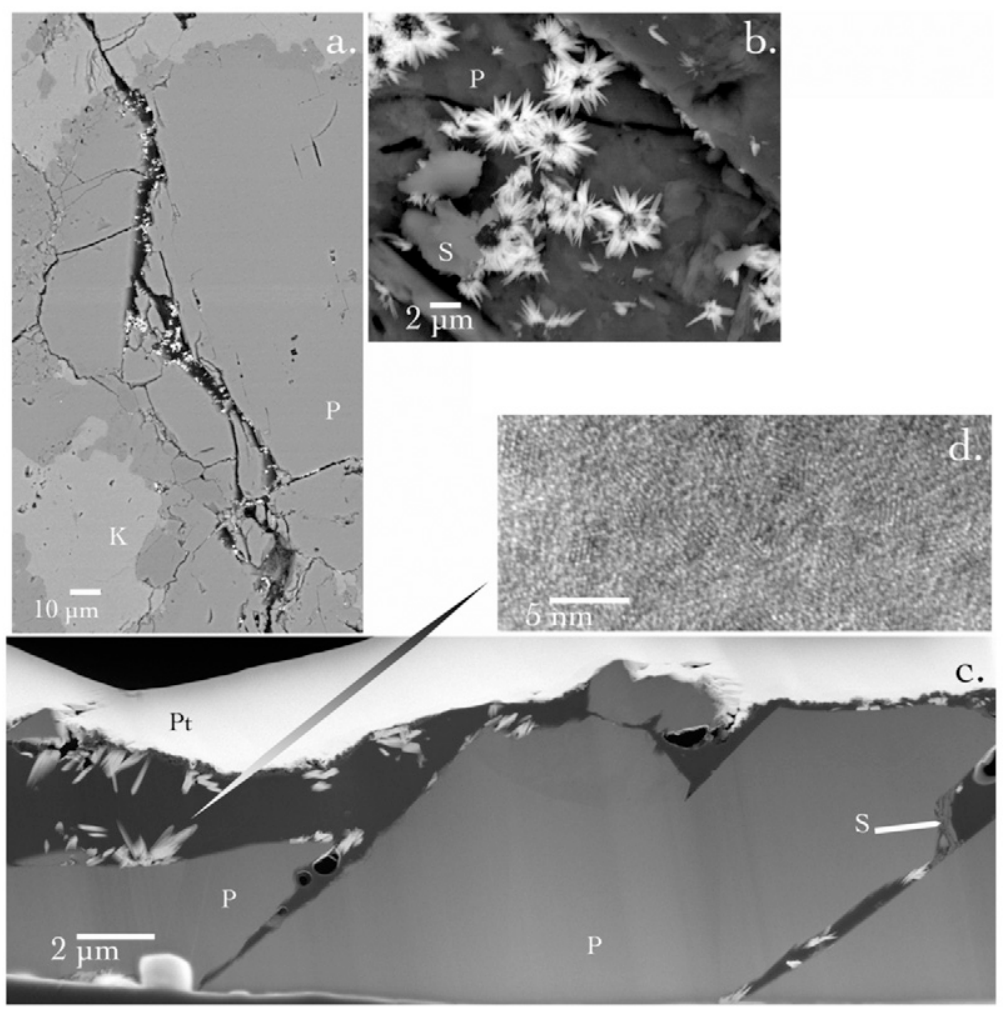

FIG. 5. Uranium silicate mineralization in core samples was confined to intragrain microfractures in granitic lithic clasts. ( $a$ and $b$ ) Backscattered electron images of nm-scale uranyl silicate florettes in fractures; K: potassium feldspar, P: plagioclase feldspar, S: smectite secondary mineralization. (c) Cross-section in transmission electron microscope image of florettes on the fracture face; Pt: platinum coating applied by focused ion beam tool. (d) transmission electron image of microcrystalline uranyl silicate domains within a uranyl silicate.

Experiments to determine the kinetics of uranium removal by dissolution (Liu et al., 2004) used electrolytes of differing composition and tracked the aqueous uranyl concentration resulting from leaching in suspension. The leach solutions were calculated to reach thermodynamic equilibrium with respect to solid sodium boltwoodite. A dissolution-diffusion model parameterized similarly to the diffusion precipitation model was constructed to describe the evolution of uranyl from its occurrence in microfractures to its mineral-saturation maximum in pore solutions (Fig. 6). The model simulated the removal of uranium from a constrained physical environment. For the example shown in Fig. 6, and for other representatives of the contaminated environment in borehole 299-E33-45, the evolution of pore solutions over varying $\mathrm{pH}$ with respect to uranyl concentration most closely corresponded to control by sodium boltwoodite (Liu et al., 2004).

Within the limitations imposed by core sampling, the uranium lost during the 1951 spill was apparently confined to a relatively narrow band of sediment in the vadose zone at approximately $43 \mathrm{~m}(140 \mathrm{ft}) \mathrm{bgs}$, in a chemical and physical form that was resistant to remobilization. This conclusion was supported by gamma logging results obtained from well 299-E33-18 (Fig. 2) in 1992 (not shown), in which uranium was not observed. The cored borehole, 299-E33-45, was within a few meters of tank BX-102. Its placement was intended to intercept the subsurface plume of uranium left by downward-migrating tank waste, and was influenced by tank farm infrastructure. Drilling within the lithologically heterogeneous gravelly sediments of the Hanford formation often results in vertical deviations as the hole progresses, and any borehole represents an essentially one-dimensional transect of a three-dimensional subsurface environment. The interpretation of the borehole measurements and of the analysis of samples removed by coring was thus limited by the obscurity of their relationship to three-dimensional contaminant distributions. Other data indicated that contaminants from the 1951 leak at BX-102 were not confined to the restricted zone at approximately $43 \mathrm{~m}$ (140 ft) bgs but migrated to the aquifer and are still moving through the deep vadose zone. Groundwater monitoring of a family of wells in the 200 East Area in the 1990s detected a groundwater contaminant plume, $250 \mathrm{~m}$ wide and $900 \mathrm{~m}$ long, in an area beneath and adjacent to the B-BX-BY tank farm (Dresel et al., 2002). The origin of the contaminant plume was not evident from routine analyses of groundwater. To investigate plume origin, multiple-collector high-precision uranium isotopic analyses were conducted of samples of vadose zone contamination and of groundwater (Christensen et al., 2004). The isotope ratios ${ }^{236} \mathrm{U} /{ }^{238} \mathrm{U},{ }^{234} \mathrm{U} /{ }^{238} \mathrm{U}$, and ${ }^{238} \mathrm{U} /{ }^{235} \mathrm{U}$ were used to distinguish contaminant sources and indicated that the source of the groundwater contamination was the 1951 overflow event at tank BX-102. The uranium isotopic variation of the groundwater plume was deduced to result from mixing between contaminant uranium from this leak and natural background uranium in the vadose zone. Comparison of the locus of groundwater contamination with the position of BX-102 indicated that lateral migration in the vadose zone was at least eight times
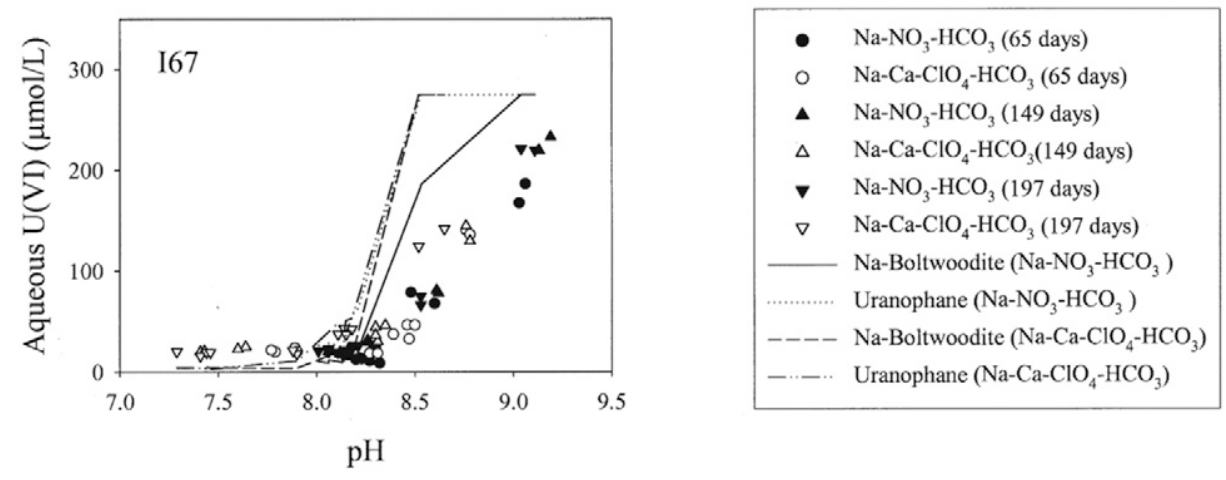

FIG. 6. Observed and modeled uranyl silicate dissolution results. Model results assume several solid phases; results most nearly conform to sodium boltwoodite dissolution. 
greater than vertical migration, and the time evolution of the groundwater plume suggested an average $U$ migration rate of 0.7 to $0.8 \mathrm{~m} \mathrm{day}^{-1}$ showing slight retardation relative to a groundwater flow of $1 \mathrm{~m} \mathrm{day}^{-1}$ (Christensen et al., 2004).

Data collected from 1992 to 2006 suggest that waste migration in the vadose zone continued. Gamma spectral logging of monitoring well 299-E33-18 (Fig. 2 and Fig. 7) showed a temporal increase of uranium and cobalt within the lower vadose zone (McCain, 2006). As noted above, uranium was not detected during logging in 1992. The maximum activity of ${ }^{238} \mathrm{U}$ for the logging results shown in Fig. 7 (at $236 \mathrm{ft}$. bgs) was $1237 \mathrm{pCi} \mathrm{g}^{-1}$, and neutron density logging results (not shown) indicated a moisture content for this interval of approximately 34 volume percent. The equivalent uranium concentration in the pore water was thus approximately 6600 $\mathrm{mg} \mathrm{L}^{-1}\left(27.7 \mathrm{mmol} \mathrm{L}^{-1}\right)$. The stratigraphic horizon where vadose uranium was observed to increase was coincident with a moisture anomaly, and with a zone of perched water, perhaps equivalent to the perched-water zone noted in 299-E33-45 (Fig. 4). The migration of contaminant uranium along a confining layer just above the groundwater level would be consistent with the observation of lateral migration in large excess of the vertical migration noted within isotopic studies of contaminant origin (Christensen et al., 2004), which could explain the occurrence of an expanding groundwater plume adjacent to the B-BX-BY tank farm.

The analysis of isotopic signatures for the nearby groundwater uranium plume, the physical relationships of uranium contamination zones, and the detection of mobile uranium near the water table adjacent to the B-BX-By tank farm indicated that the 1951 spill could be responsible for the expanding uranium groundwater plume discussed previously (Christensen et al., 2004; Dresel et al., 2002). Closer inspection of the spectral logging results for boreholes 299-E33-45, 299-E33-41, and 299-E33-18 (Fig. 2), however, indicated that the uranium represented in these boreholes had disparate activity ratios for ${ }^{235} \mathrm{U}:{ }^{238} \mathrm{U}$ (Fig. 8). The activity of ${ }^{235} \mathrm{U}:{ }^{238} \mathrm{U}$ for $299-\mathrm{E} 33-45$ was 0.04 , and the activity of ${ }^{235} \mathrm{U}:{ }^{238} \mathrm{U}$ for $299-\mathrm{E} 33-18$ was 0.08. (The trend lines indicating the ratios on Fig. 8 were constructed by plotting lines along which the data tended to cluster, particularly at higher concentrations. It should not be assumed that the ratios were precisely known, since the trend lines are meant to provide a comparison of the clusters.) The latter borehole, therefore, apparently included twice the proportional ${ }^{235} \mathrm{U}$ as the former, and the contaminant uranium, therefore, apparently must have had a different source. This interpretation was complicated in turn, however, by the method of measurement
299-E33-18 (A4844)

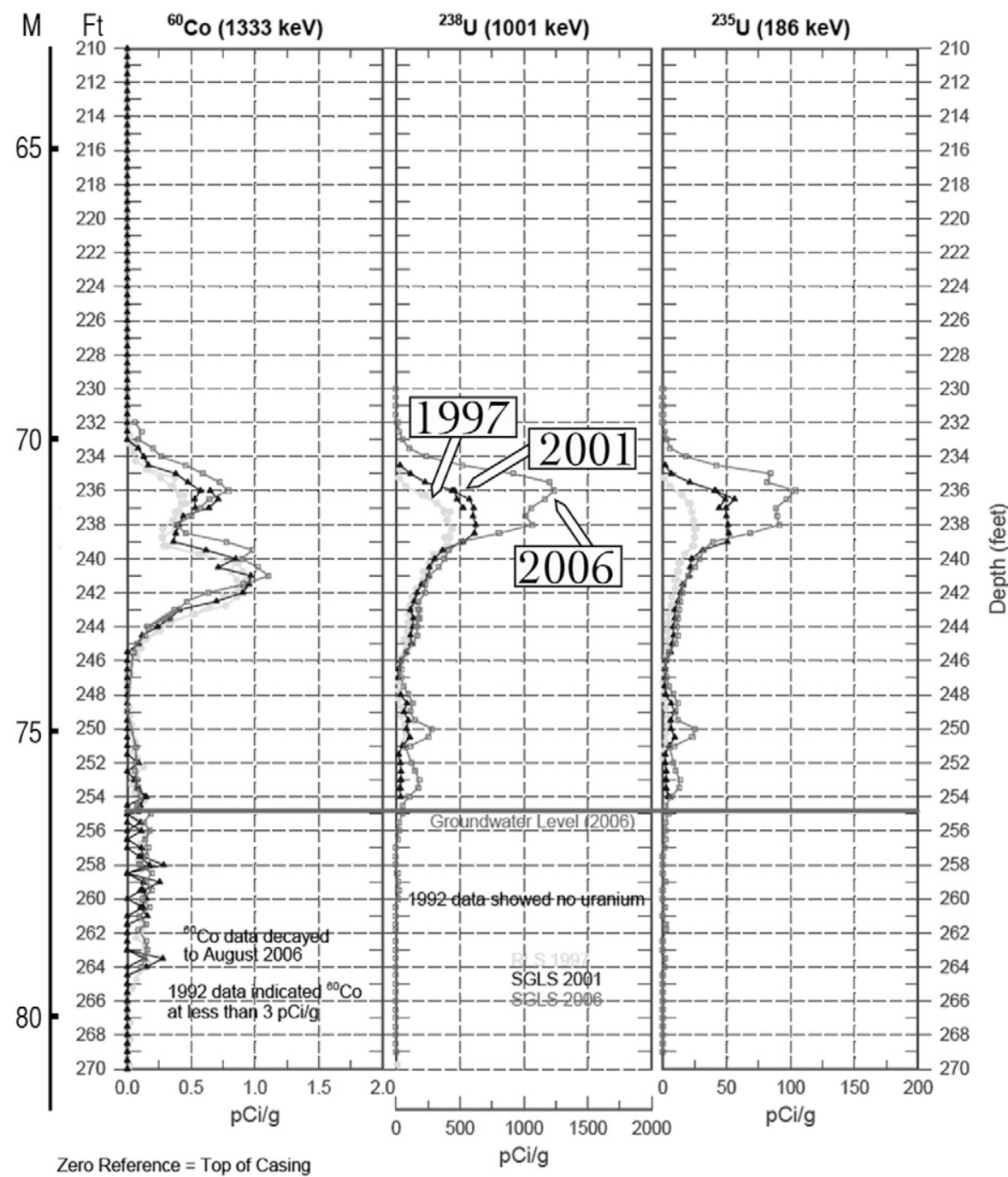

FIG. 7. Spectral gamma logging results for borehole 299-E33-18, showing the accumulation of vadose-zone uranium and cobalt. (Courtesy of S.M. Stoller Co.)

and calculation and the mobility of the vadose uranium plume. The spectral gamma logging result relied on the direct detection of ${ }^{235} \mathrm{U}$ through its $\alpha$ decay and coincident $\gamma$ emission, and the decay and detection of ${ }^{238} \mathrm{U}$ by the indirect measurement of its decay through ${ }^{234} \mathrm{Th}$ to ${ }^{234} \mathrm{~Pa} .{ }^{238} \mathrm{U}$ decays by $\alpha$-emission with a half-life of 4.5 billion years to ${ }^{234} \mathrm{Th}$, which decays by $\beta$ emission with a half-life of $24 \mathrm{~d}$ to ${ }^{234} \mathrm{~Pa}$, which decays by detectable $\gamma$ emission with a half-life of 1.2 min to ${ }^{234} \mathrm{U}$ (McCain et al., 2006). Since secular equilibrium of daughter products with the parent isotope is reached within approximately seven half-lives, the ${ }^{234} \mathrm{~Pa}$ would be in secular equilibrium with ${ }^{234} \mathrm{Th}$ within about $10 \mathrm{~min} .{ }^{234} \mathrm{Th}$ would require approximately $6 \mathrm{mo}$ to reach secular equilibrium with respect to ${ }^{238} \mathrm{U}$, and the calculation of ${ }^{238} \mathrm{U}$ activity by detection of $\gamma$ radiation from ${ }^{234} \mathrm{~Pa}$ relied on the assumption of isotopic equilibrium between ${ }^{234} \mathrm{Th}$ and ${ }^{238} \mathrm{U}$. These two isotopes may not have been in secular equilibrium at the borehole. The increase in uranium concentration detected by logging (Fig. 7) defined the uranium plume as being in movement. Analogous to uranium, thorium mobility is limited by 
sorption processes acting along its flow path: the differential sorption and retardation of thorium during the vadose infiltration illustrated in Fig. 7 could result in an anomalous low estimated activity of ${ }^{238} \mathrm{U}$, since secular equilibrium would be interrupted by the removal of thorium. The relative abundance of ${ }^{234} \mathrm{Th}$ to ${ }^{238} \mathrm{U}$ at secular equilibrium is 1.5 $\times 10^{-11}$, so the removal of a very small absolute quantity of thorium could result in a large change in apparent ${ }^{235} \mathrm{U}:{ }^{238} \mathrm{U}$. This hypothesis was consistent with published research on the sorptive partitioning of Th. For example, a direct measurement of distribution coefficients $\left(K_{\mathrm{D}}=\left[\mu \mathrm{g} \mathrm{g}^{-1}\right.\right.$ solid $/ \mu \mathrm{g}$ $\mathrm{mL}^{-1}$ liquid]) for uranium and thorium on natural soils (Syed, 1998) resulted in a differential of two orders of magnitude (i.e., $\log K_{\mathrm{D} \text { Th }}=$ 5.8 vs. $\log K_{\mathrm{D} U}=3.38$ in dilute electrolytes). A study of disequilibrium decay series in a basaltic aquifer in Idaho (Luo et al., 2000) showed a potentially greater disparity in nature, with rapid sorption and "retardation factors," $R_{\mathrm{E}}$, including the effects of sorption, precipitation, and $\alpha$ recoil, yielding $R_{\mathrm{Th}}>10^{7} ; R_{\mathrm{U}} \sim 10^{3}$. The differential retardation during subsurface migration, allowing also for the complicating possibility of differential removal and partial regeneration of ${ }^{234} \mathrm{Th}$ could thus explain the apparent disparity in ${ }^{235} \mathrm{U}:{ }^{238} \mathrm{U}$ between the boreholes represented in Fig. 8. The potential effects of isotopic disequilibrium within the migrating uranium plume introduced uncertainty into the interpretation of the gamma logging results but were conjectural and represented a testable hypothesis that could be resolved by further experimentation and analysis.

An experimental investigation of simulated waste and Hanford formation sediment also produced results relevant to the possible origin of 299-E22-18 uranium from the BX-102 spill. These data suggested that the magnitude of uranium concentration calculated for the uranium plume might be the result of dilution of the original waste form and uranium exchange with vadose sediments during migration to depth. The estimated deep vadose concentration of $6600 \mathrm{mg} \mathrm{U} \mathrm{L}^{-1}$ (McCain, 2006) was compared with the estimates of contaminant composition, that is, 26,000 mg U L ${ }^{-1}$ (0.11 mol U L $\left.{ }^{-1}\right)$ (Jones et al., 2001), representing a reduction of solute uranium by $75 \%$ during migration. In a series of experiments described in detail elsewhere (Wan, unpublished data, 2007), representative Hanford formation sediments were imbibed with alkaline simulated wastes at a $\mathrm{pH}$ of 10.4 .
Uranium X-plot

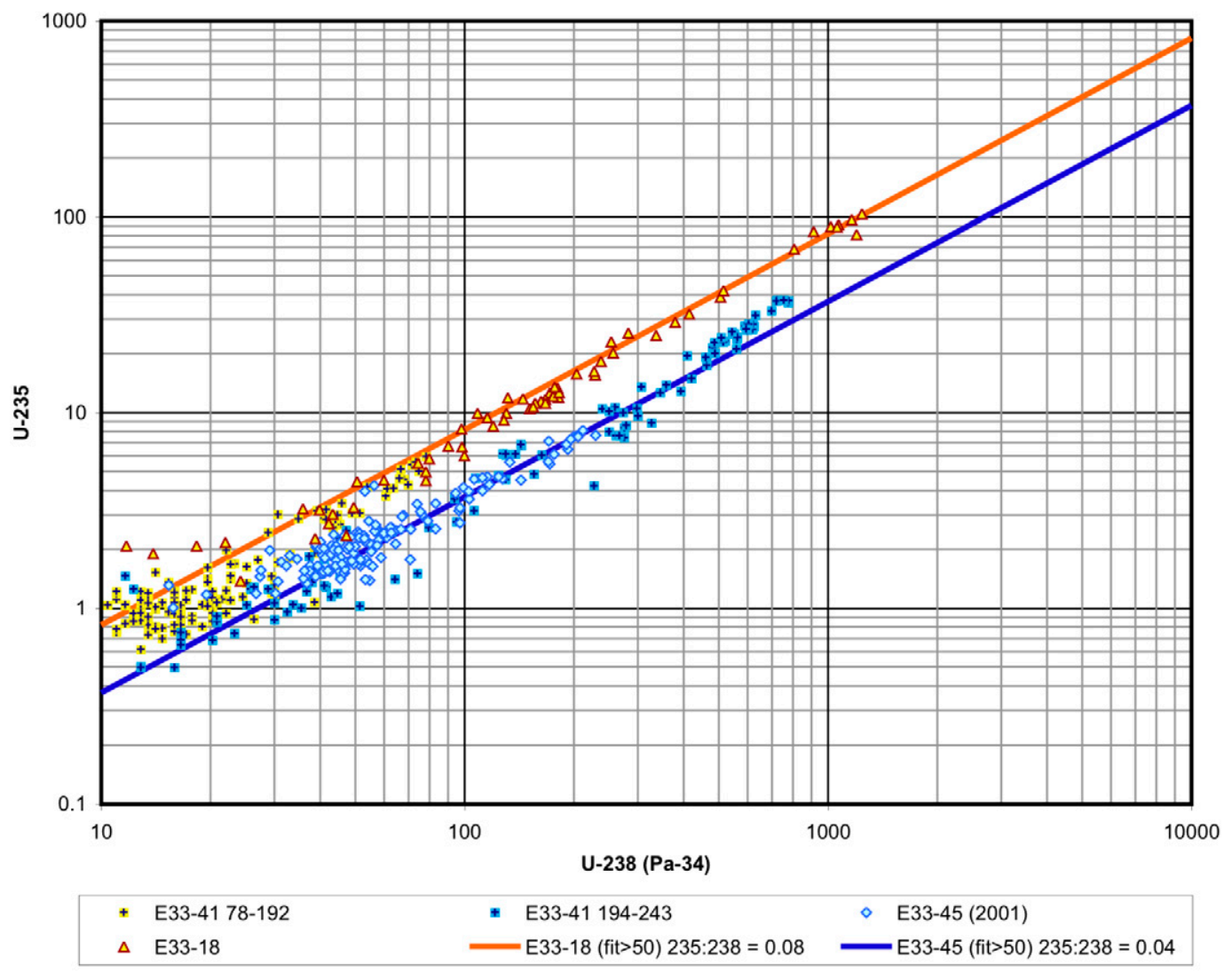

FIG. 8. Log-log plot of $235 \mathrm{U}$ vs. $238 \mathrm{U}$ for boreholes 299-E33-45, 299-E33-41, and 299-E33-18. $238 \mathrm{U}$ is derived from 234Pa activity. The ratio of 235U:238U apparently varies from 0.04 in 299-E33-45 to 0.08 in 299-E33-18. Results for 299-E33-41 are split according to depth (shown), and are intermediate in isotopic ratios and agree with the ratios of both other boreholes. (Courtesy of S.M. Stoller Co.)

Temporally and spatially resolved chemical and physical properties of plume pore liquids and sediments were determined to obtain profiles of geochemical characteristics (Fig. 8). Initially, all of the added uranium was within the pore fluid (Fig. 9a). As the pore water-sediment system aged, however, $\mathrm{pH}$ was moderated toward neutral values (not shown), and the interaction of the alkaline aqueous phase with Hanford formation sediment apparently
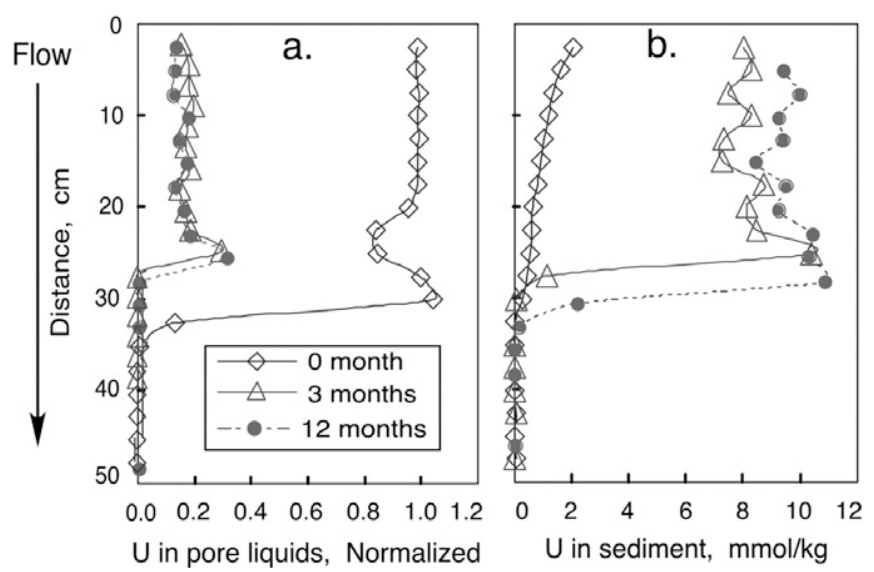

FIG. 9. Results of timed imbibation experiments using Hanford formation sediment samples and simulated waste solutions. Experiments were conducted in columns and approximate the accumulation of uranium in the vadose zone. 
stimulated sorption and precipitation of uraniumbearing secondary phases. After aging for $12 \mathrm{mo}$, $80 \%$ of the uranium was partitioned to the solid phase (Fig. 9b); the aqueous concentration was reduced to approximately $5200 \mathrm{mg} \mathrm{L}^{-1}$. If the experimental results represented equilibration of the original waste with sediment, dependent on solubility and sorption relationships with $\mathrm{pH}$, then they could be analogous to the observations from the field. The observed vadose plume near the water table would thus be a reacted residuum from the original waste spill. This interpretation, again, was conjectural but testable with further field sampling.

\section{The 300 Area Leak}

Although the surface sources of the 300 Area uranium plume were long-since excavated and removed, a significant groundwater concentration of uranium persists and migrates to the environmentally sensitive Columbia River, particularly through the interface between groundwater and the riverbed. The persistence of the plume suggested that the Hanford formation sediments in the vadose zone provided a solid-phase source of uranium to groundwater. Excavated samples from the vadose zone beneath the excavated ponds were examined microscopically and showed the presence of varying amounts of uranium and copper-bearing secondary mineralization.

For comparison, a sample from the excavated pond sediment was examined (Fig. 10, NP 4-1). Although the excavated sediment included mineral clasts, waste precipitates, predominantly aluminosilicate, were the most abundant component. Uranium was present as minute uraniumrich inclusions in the aluminosilicate matrix but was also broadly disseminated at low concentrations within the matrix. The waste clasts were compositionally heterogeneous, as indicated by elemental abundance maps for silicon and calcium, showing the incorporation of both minerals and the secondary matrix.

The vadose sediments (Fig. 10, NPP 2-0.5 and NPP 2-4), were predominantly mineral and lithic clasts but were coated with aluminosilicate mineralization. In the EMP images shown in Fig. 10, this coating was apparent, but the incorporation of uranium was evidently different from that in primary process pond wastes. The figure includes backscattered electron images of samples NP 4-1 and NPP 2-4 (the image of sample NPP2-05 was similar to NPP2-4 and was omitted for brevity); the morphology of the NPP aluminosilicate coating was similar to the NP process pond precipitates, and the compositional heterogeneity of the coating in the NP and NPP samples was similar (calcium and silicon abundance maps showed a similar compositional texture), except with respect to uranium. Disseminated uranium in the NPP samples was absent or below the detection limit for EMP analysis. In addition, the abundance of uraniumrich inclusions in the NPP samples decreased with depth and in the NPP2-4 samples, was observed as sparsely distributed minute blebs (Fig. 10). Spectroscopic and $\mu \mathrm{X}$-ray diffraction investigations of NPP sediments suggested that the uranium-rich mineral was metatorbernite $\left[\mathrm{Cu}\left(\mathrm{UO}_{2} \mathrm{PO}\right) \cdot 8 \mathrm{H}_{2} \mathrm{O}\right]$ (Arai et al., 2007; Catalano et al., 2006). There was also a significant calcium carbonate component, which could contribute to the lowabundance uranium component through substitution of uranyl for calcium (Kelly et al., 2003).

To investigate whether uranium persisted with depth into the vadose NPP environment, a more sensitive methodology than EMP analysis was required. The XMP and X-ray absorption spectroscopy methodology has been used in combination with SEM images to provide sensitive compositional information along with detailed morphology (Fredrickson et al., 2004; McKinley et al., 2004, 2005). Samples NPP 2-4 and NPP 116 (Fig. 11) were examined to determine whether uranium was detectible at depth. The backscattered electron image for sample NPP2-4 showed that the mineral clasts were coated with aluminosilicate mineralization. The false-color EMP abundance maps were adjusted to reveal the presence of copper and uranium at 

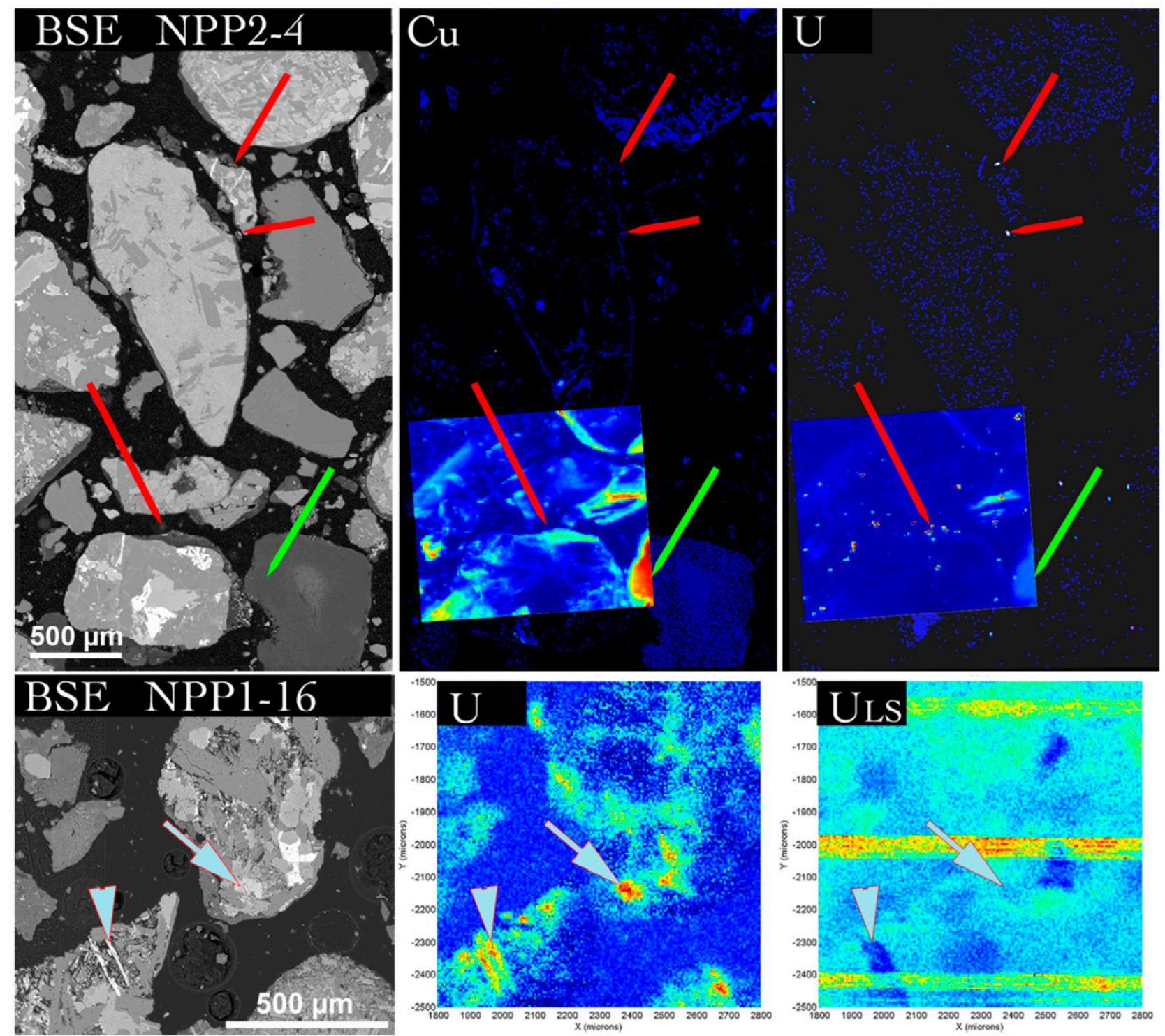

FIG. 11. Electron microprobe and X-ray microprobe analyses of copper and uranium in deeper North Process Pond (NPP) sediments. Dissemi-

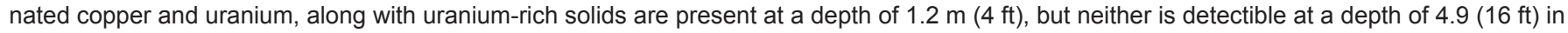
Sample NPP 1-16, included for reference, even using the X-ray microprobe. Sample NPP 2-4 includes a backscattered electron image and electron microprobe elemental abundance maps, overlain by X-ray microprobe abundance maps. The red arrows indicate occurrence of uranium-rich mineralization; the green arrow indicates an area of disseminated copper and uranium.

the lowest detectible levels (the solid-phase concentrations were not determined). The presence of copper in clast coatings was apparent, but obscured by the similarity in intensity to background (coatings were apparent in the EMP copper elemental abundance map of Fig. 10, but background signals within some silicate portions of the clasts were displayed as copper also). Uranium was only observed in uranium-rich inclusions in the EMP portions of the images (red arrows). An overlay of XMP results on EMP maps, however, showed copper within the aluminosilicate clast coatings, and confirmed the presence of compositionally mottled aluminosilicate clasts (Fig. 11, green arrow) containing copper and uranium, similar to the major component of NP samples (Fig. 10). The uranium abundance map was consistent with the Fig. 10 results for uranium-rich inclusions (Fig. 11, red arrows), and for the presence of much lower concentrations of uranium in low-abundance aluminosilicate coat- ings. Results for sample NPP 1-16 (Fig. 11) were more difficult to interpret. The uranium X-ray abundance was monitored with two detectors, an energy dispersive detector and a wavelength dispersive detector, in the XMP, and the sample was subsequently imaged using the EMP. The energy dispersive detector appeared to detect uranium; the areas of high abundance, however, were coincident with iron-rich phases visible in backscattered electron imaging (confirmed by Fe abundance maps, not shown; Fig. 11, blue arrows). The more sensitive wavelength dispersive detector showed very noisy but very low abundances for uranium at these locations. Apparently, the energy dispersive detector was interpreting $\mathrm{Fe} \mathrm{K} \alpha$ coincidence X-rays as U L $\alpha \mathrm{X}$-rays; the "noisy" wavelength dispersive image corresponds to no detectible uranium in the sample.

The inclusion of uranium-rich minerals and of disseminated copper and uranium in aluminosilicate coatings on sedi- 
ment clasts suggested that they were the result of aluminate-rich wastes migrating into the vadose zone and precipitating after reaction with sediment components. Samples of the coatings were removed for X-ray diffraction analysis by direct manipulation and scraping under a binocular microscope; the procedure yielded samples that were minute and not uniform in mass but which provided major-phase mineral identification of the coatings (Fig. 12). Two mineral components were identified: clinochlore and muscovite, labeled " $\mathrm{C}$ " and " $\mathrm{M}$," respectively in the 5 to $15^{\circ}$ two-theta scan in Fig. 12. It is unlikely that these minerals were precipitated from process pond wastes, given their welldeveloped crystal structure. These two minerals are common and ubiquitous components of the Hanford formation and so represent preexisting detrital minerals in the fine-fraction of the vadose sediments. A reasonable interpretation of the microscale distributions of copper and uranium presented here is that the continuous leakage of process pond wastes, or the periodic leakage of low-pH wastes, into the vadose zone caused reaction with the detrital aluminosilicate minerals and pore-fluid phosphate. The uranium and copper associated with the aluminosilicates may represent sorbed cations or could represent secondary mineralization under alkaline or acidic regimes. Microscale Xray spectroscopy and $\mu \mathrm{X}$-ray diffraction of these sediments also identified the presence of uranophane $\left(\mathrm{Ca}\left[\mathrm{UO}_{2}\right]_{2}\left[\mathrm{SiO}_{3}(\mathrm{OH})\right]\right.$ $\left.2.5 \mathrm{H}_{2} \mathrm{O}\right)$ and uranium-associated muscovite, along with metatorbernite (Arai et al., 2007). The association of uranium with the aluminosilicate matrix at microscale (Fig. 10, 11) is consistent with and supportive of the spectroscopic evidence; uranophane was not observed here. The NPP sediments also contain significant calcium carbonate (Zachara et al., 2005), apparently also at a scale that was smaller than we could readily observe using SEM methods. The overall evidence suggests that solidphase uranyl, in uranium-rich solid phases and broadly disseminated at low-concentrations associated with detrital aluminosilicates, represents a pool of solid-phase reactant that supplies the groundwater uranium plume.

\section{Summary and Conclusions}

Contaminant uranium at the 200 Area BX tank farm and at the 300 Area Process Pond sites resided in secondary mineralization that was derived from the original waste forms and differed at the two sites according to the original waste composition. At the 200 Area, the alkaline, silica-poor waste of large volume and alkaline $\mathrm{pH}$ reacted with Hanford formation sediments to invade clasts of particular lithology and to form relatively isolated solid uranyl silicate phases. At the 300 Area, the continuous leakage to the subsurface, whether of alkaline or acidic wastes laden with abundant copper, uranium, and aluminate, allowed the permeation of high-surface-area aluminosilicates and the formation of several uranyl-bearing solid phases. The formation of low-solubility uranyl phosphate (metatorbernite) at the 300 Area may have been facilitated by the large fluctuations in $\mathrm{pH}$ - and thus the local solubility of uranyl as secondary hydroxides, carbonates, or sorbed species — combined with aquifer supplies of dissolved phosphate. Local, random nucleation of uranyl phosphate, analogous to localized nucleation of uranyl silicate in the 200 Area sediments, may have provided control on the distribution of metatorbernite by inhibiting nucleation

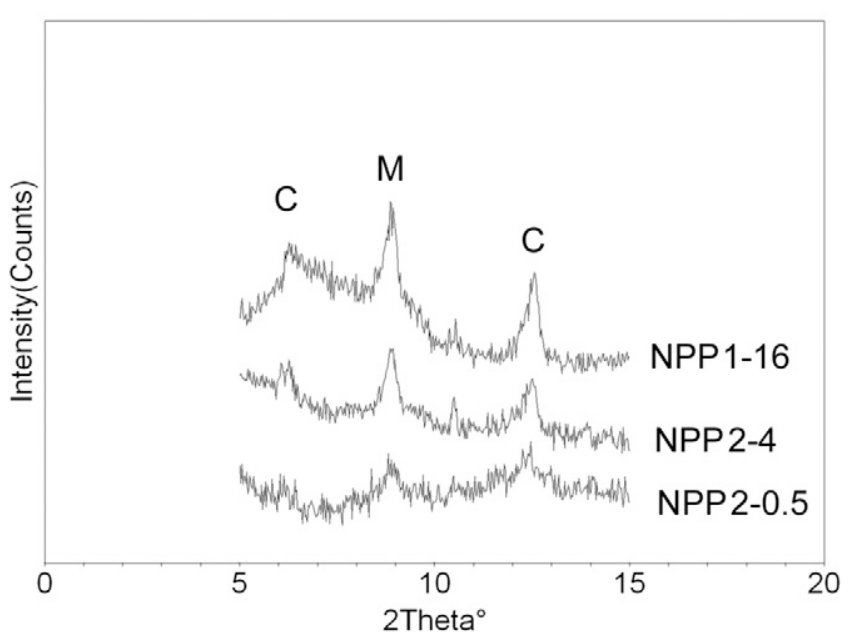

FIG. 12. X-ray diffraction analysis over the two-theta range of 5 to 10 degrees; C: chlinochlore; M: muscovite.

within a very local diffusion gradient. The combination of solid phases of variable reactivity and solubility warrants investigation as a compound source of uranyl to groundwater through iterative and incremental reaction and equilibration with migrating pore waters.

The results from the 200 Area illustrate the difficulty of investigating the complicated contaminated systems in the vadose and saturated environments at Hanford. The subsurface and groundwater samples were limited, their geologic setting was physically heterogeneous, and the interpretation of the measurements was difficult. The results and discussion above represent interpretations of the origin and behavior of uranium beneath the B-BX-BY tank farm, consistent with the data available. The interpretations relied on hypotheses that require further testing for resolution, particularly with regard to the origin of the groundwater contaminant plume east of the tank farm.

The results presented here represent intensive efforts to understand the behavior of contaminant uranium at the sites studied, but they also indicate limitations on our knowledge of these spills and the threat they pose to the environment. For the 200 Area study, the construction of borehole 299-E33-45 was intended to sample and characterize the vadose zone uranium spill. The logging data and isotopic studies suggest, however, that the borehole transected the contamination lobe but did not completely capture its spatial and compositional range. For the 300 Area study, samples showed that uranyl contamination was entrained in a number of solid phases that together represented a persistent source of uranium to the groundwater entering the Columbia River. The distribution of uranium was not determined by the limited subaerial extent of the sampling, and we do not have detailed information concerning the migration of dissolved uranium into the groundwater environment.

With respect to widespread uranium contamination at the Hanford Site, our results suggest that the mobility of uranium in a relatively uniform lithologic environment was dependent on the composition of the waste as it entered the vadose zone, which determined the chemical form of secondary mineralization that subsequently controlled uranium mobility. Uranium contamination emplaced in the Hanford formation was heterogeneous and could vary within a single contaminant plume as a result 
of waste-sediment interaction that altered the composition of secondary phases formed during migration. Intensive, detailed field sampling and analysis are necessary to fully understand and predict the future behavior of uranium at this site.

\section{ACKNOWLEDGMENTS}

This research was supported by the Hanford Tank Farm Vadose Zone Project managed by CH2M-HILL Hanford Group, Inc., and by the USDOE Office of Biological and Environmental Research (OBER) Environmental Remediation Sciences Program (ERSP). Pacific Northwest National Laboratory is operated for the USDOE by the Battelle Memorial Institute. A portion of the research described in this paper was performed in the Environmental Molecular Sciences Laboratory, a national scientific user facility sponsored by the USDOE OBER and located at Pacific Northwest National Laboratory.

\section{References}

Anderson, R.F., M.Q. Fleischer, and A.P. LeHuray. 1989a. Concentration, oxidation state, and particle flux of uranium in the Black Sea. Geochim. Cosmochim. Acta 53:2215-2224.

Anderson, R.F., A.P. LeHuray, M. Fleischer, and J.W. Murray. 1989b. Uranium deposition in Saanich Inlet sediments, Vancouver Island. Geochim. Cosmochim. Acta 53:2205-2213.

Anderson, R.T., H.A. Vrionis, I. Ortiz-Bernad, C.T. Resch, P.E. Long, R. Dayvault, K. Karp, S. Marutzky, D.R. Metzler, A.D. Peacock, D.C. White, M. Lowe, and D.R. Lovley. 2003. Stimulating the in situ activity of Geobacter species to remove uranium from the groundwater of a uraniumcontaminated aquifer. Appl. Environ. Microbiol. 69:5884-5891.

Arai, Y., M.A. Marcus, N. Tamura, J.A. Davis, and J.M. Zachara. 2007. Spectroscopic evidence for uranium bearing precipitates in vadose zone sediments at the Hanford 300-Area site. Environ. Sci. Technol., doi:10.1021/es062196u.

ASTM. 1998. Standard test method for particle-size analysis of soils, method D42263. American Society for Testing and Materials, West Conshohoken, PA

Baes, C.F., Jr., and R.E. Mesmer. 1976. The hydrolysis of cations. John Wiley $\&$ Sons, New York.

Barnes, C.E., and J.K. Cochran. 1993. Uranium geochemistry in estuarine sediments: Controls on removal and release processes. Geochim. Cosmochim. Acta 57:555-569.

Bjornstad, B.N. 1990. Geohydrology of the 218-W-5 burial ground, 200-West Area, Hanford Site. PNL-7336. Pacific Northwest Laboratory, Richland, WA.

Bjornstad, B.N., K.R. Fecht, and A.M. Tallman. 1987. Quaternary geology of the Pasco Basin, Washington. RHO-BW-SA-563A. Rockwell Hanford Operations, Richland, WA.

Catalano, J.G., S.M. Heald, J.M. Zachara, and G.E. Brown, Jr. 2004. Spectroscopic and diffraction study of uranium speciation in contaminated vadose zone sediments from the Hanford Site, Washington State. Environ. Sci. Technol. 38:2822-2828.

Catalano, J.G., J.P. McKinley, J.M. Zachara, S.M. Heald, S.C. Smith, and G.E. Brown, Jr. 2006. Changes in uranium speciation through a depth sequence of contaminated Hanford sediments. Environ. Sci. Technol. 40:2517-2524.

Christensen, J.N., P.E. Dresel, M.E. Conrad, K. Maher, and D.J. DePaolo. 2004. Identifying the sources of subsurface contamination at the Hanford Site in Washington using high-precision uranium isotopic measurements. Environ. Sci. Technol. 38:3330-3337.

Dresel, P.E., J.C. Evans, and O.T. Farmer, Jr. 2002. Investigation of isotopic signatures for sources of groundwater contamination at the Hanford Site. PNNL-13763. Pacific Northwest National Laboratory, Richland, WA.

Finch, R., and T. Murakami. 1999. Systematics and paragenesis of uranium minerals. p. 91-179. In P.C. Burns and R. Finch (ed.) Uranium: Mineralogy, geochemistry, and the environment. Mineralogical Society of America, Washington, DC.

Finneran, K.T., R.T. Anderson, K.P. Nevin, and D.R. Lovley. 2002. Potential for bioremediation of uranium-contaminated aquifers with microbial U(VI) reduction. Soil Sedim. Contam. 11:339-357.

Fredrickson, J.K., J.M. Zachara, D.W. Kennedy, R.K. Kukkadapu, J.P. McKinley, S.M. Heald, C. Liu, and A.E. Plymale. 2004. Reduction of
$\mathrm{TcO}_{4}^{-}$by sediment-associated biogenic $\mathrm{Fe}(\mathrm{II})$. Geochim. Cosmochim. Acta 68:3171-3187.

Grenthe, I., J. Fuger, R.J.M. Konings, R.J. Lemire, A.B. Muller, C. NguyenTrung, and H. Wanner. 1992. Chemical thermodynamics of uranium. Elsevier/North-Holland, New York.

Heald, S.M., D.L. Brewe, E.A. Stern, K.H. Kim, F.C. Brown, D.T. Jiang, E.D. Crozier, and R.A. Gordon. 1999. XAFS and micro-XAFS at the PNCCAT beamlines. J. Synchrotron Radiat. 6:347-349.

Heaney, P.J., E.P. Vicenzi, L.A. Giannuzzi, and K.J.T. Livi. 2001. Focused ion beam milling: A method of site-specific sample extraction for microanalysis of Earth materials. Am. Mineral. 86:1094-1099.

Hooper, P.R. 1982. The Columbia River Basalts. Science 215:1463-1468.

Hsi, C.-K.D., and D. Langmuir. 1985. Adsorption of uranyl onto ferric oxhyhydroxides: Application of the surface complexation site-binding model. Geochim. Cosmochim. Acta 49:1931-1941.

Idiz, E.F., D. Carlisle, and I.R. Kaplan. 1986. Interaction between organic matter and trace metals in a uranium rich bog, Kern County, California, U.S.A. Appl. Geochem. 1:573-590.

Jones, T.E., B.C. Simpson, M.I. Wood, and R.A. Corbin. 2001. Preliminary inventory estimates for single-shell tank leaks in B, BX, and BY tank farms. RPP-7389. CH2M HILL Hanford Group, Richland, WA.

Kelly, S.D., M.G. Newville, L. Cheng, K.M. Kemner, S.R. Sutton, P. Fenter, N.C. Sturchio, and C. Spotl. 2003. Uranyl incorporation in natural calcite. Environ. Sci. Technol. 37:1284-1287.

Langmuir, D. 1978. Uranium solution-mineral equilibria at low temperatures with applications to sedimentary ore deposits. Geochim. Cosmochim. Acta 42:547-569.

Leventhal, J.S., and T.A. Dawn. 1986. Organic geochemical analysis of sedimentary organic matter associated with uranium. Appl. Geochem. $1: 241-247$.

Lieser, K.H., S. Quandt-Klenk, and B. Thybusch. 1992. Sorption of uranyl ions on hydrous silicon dioxide. Radiochim. Acta 57:45-50

Liu, C., J.M. Zachara, N. Qafoku, J.P. McKinley, S.M. Heald, and Z. Wang. 2004. Dissolution of uranyl microprecipitates from subsurface sediments at Hanford Site, USA. Geochim. Cosmochim. Acta 68:4519-4537.

Lomness, L.K., B.W. Kempshall, L.A. Giannuzzi, and M.B. Watson. 2001. TEM of sub-micrometer particles using the FIB lift-out technique. Microsc. Microanal. 7(Suppl. 2):950-951.

Lovley, D.R. 1993. Dissimilatory metal reduction. Annu. Rev. Microbiol. 47:263-290.

Lovley, D.R., E.J.P. Phillips, Y.A. Gorby, and E.R. Landa. 1991. Microbial reduction of uranium. Nature 350:413-416.

Luo, S., T.-L. Ku, R. Roback, M. Murrell, and T. McCling. 2000. In-situ radionuclide transport and preferential groundwater flows at INEEL (Idaho): Decay-series disequilibrium studies. Geochim. Cosmochim. Acta 64:867-881.

Maya, L. 1982. Sorbed uranium(VI) species on hydrous titania, zirconia, and silica gel. Radiochim. Acta 31:147-151.

McCain, R., P. Henwood, and C. Koizumi. 2006. Detection and quantification of natural and anthropogenic uranium by high-resolution spectral gamma logging. HGLP-LDR-028. S.M. Stoller, Richland, WA.

McCain, R.G. 2006. Gamma and neutron logs of 299-E33-18. DOE-EM/ GJ1302-006. Stoller Hanford Office, Richland, WA.

McKinley, J.P., T.O. Stevens, J.K. Fredrickson, J.M. Zachara, F.S. Colwell, K.B. Wagnon, S.C. Smith, S.A. Rawson, and B.N. Bjornstad. 1997. Biogeochemistry of anaerobic lacustrine and paleosol sediments within an aerobic unconfined aquifer. Geomicrobiol. J. 14:23-29.

McKinley, J.P., J.M. Zachara, S.M. Heald, A. Dohnalkova, M. Newville, and S.R. Sutton. 2004. Microscale distribution of cesium sorbed to biotite and muscovite. Environ. Sci. Technol. 38:1017-1023.

McKinley, J.P., J.M. Zachara, C. Liu, S.M. Heald, B.I. Prenitzer, and B.W. Kempshall. 2006. Microscale controls on the fate of contaminant uranium in the vadose zone, Hanford Site, Washington. Geochim. Cosmochim. Acta 70:1873-1887.

McKinley, J.P., J.M. Zachara, S.C. Smith, and C. Liu. 2005. Cation exchange reactions controlling desorption of ${ }^{90} \mathrm{Sr}^{2+}$ from coarse-grained contaminated sediments at the Hanford Site, Washington. Geochim. Cosmochim. Acta 71:305-325.

McKinley, J.P., J.M. Zachara, S.C. Smith, and G.D. Turner. 1995. The influence of uranyl hydrolysis and multiple site-binding reactions on adsorption of 
U(VI) to montmorillonite. Clays Clay Miner. 43:586-598.

Michalsen, M.M., B.A. Goodman, S.D. Kelly, K.M. Kemner, J.P. McKinley, J.W. Stucki, and J.D. Istock. 2006. Uranium and technetium bioimmobilization in intermediate-scale physical models of an in situ biobarrier. Environ. Sci. Technol. 40:7048-7053.

Mikami, N., M. Sasaki, K. Hachiya, and T. Yasunaga. 1983. Kinetic study of the adsorption-desorption of the uranyl ion on a gamma- $\mathrm{Al}_{2} \mathrm{O}_{3}$ surface using the pressure-jump technique. J. Phys. Chem. 87:5478-5481.

Morris, D.E., C.J. Chisholm-Brause, M.E. Barr, S.D. Conradson, and P.G. Eller. 1994. Optical spectroscopic studies of the sorption of $\mathrm{UO}_{2}{ }^{2+}$ species on a reference smectite. Geochim. Cosmochim. Acta 58:3613-3623.

Plant, J.A., P.R. Simpson, B. Smith, and B.F. Windley. 1999. Uranium ore deposits: Products of the radioactive earth. p. 256-319. In P.C. Burns and R. Finch (ed.) Uranium: Mineralogy, geochemistry, and the environment. Mineralogical Society of America, Washington, DC.

Prenitzer, B.I., L.A. Giannuzzi, K. Newman, S.R. Brown, T.L. Shofner, and F.A. Irwin. 1998. Transmission electron microscope specimen preparation of $\mathrm{Zn}$ powders using the focused ion beam lift-out technique. Metall. Mater. Trans. A 29:2399-2406.

Prikryl, J.D., L. Jain, D.R. Turner, and R.T. Pabalan. 2001. Uranium ${ }^{\mathrm{VI}}$ sorption behavior on silicate mineral mixtures. J. Contam. Hydrol. 47:241-253.

Reidel, S.P., N.P. Campbell, K.R. Fecht, and K.A. Lindsey. 1994. Late Cenozoic structure and stratigraphy of south-central Washington. p. 159-180. In R. Lasmanis and E.S. Cheney (ed.) Regional geology of Washington State. Washington Division of Geology and Earth Resources Bulletin 80. Washington State Department of Natural Resources, Olympia.

Riley, R.G., and J.M. Zachara. 1992. Chemical contaminants on DOE lands and selection of contaminant mixtures for subsurface science research. DOE/ER-0547T. USDOE, Washington, DC.

Serne, R.J., B.N. Bjornstad, G.W. Gee, H.T. Schaef, D.C. Lanigan, R.G. McCain, C.W. Lindenmeir, R.D. Orr, V.L. LeGore, R.E. Clayton, M.J. Lindberg, I.V. Kutnyakov, S.R. Baum, K.N. Geiszler, M.M. Valenta, T.S. Vickerman, and L.J. Royack. 2002a. Characterization of vadose zone sediment: Borehole 299-E33-46 near B110 in the B BX-BY waste management area. PNNL-14119. Pacific Northwest National Laboratory, Richland, WA.

Serne, R.J., G.V. Last, G.W. Gee, H.T. Schaef, D.C. Lanigan, C.W. Lindenmeir, M.J. Lindberg, R.E. Clayton, V.L. LeGore, R.D. Orr, I.V. Kutnyakov, S.R. Baum, K.N. Geiszler, C.F. Brown, M.M. Valenta, and T.S. Hill. 2002b. Characterization of vadose zone sediment: Borehole 299-E33-45 near BX-102 in the B-BX-BY waste management area. PNNL-14083. Pacific Northwest National Laboratory, Richland, WA.

Suzuki, Y., S.D. Kelly, K.M. Kemner, and J.F. Banfield. 2003. Microbial populations stimulated for hexavalent uranium reduction in uranium mine sediment. Appl. Environ. Microbiol. 69:1337-1346.

Syed, H.S. 1998. Extrapolation studies on adsorption of thorium and uranium at different solution compositions on soil sediments. J. Radioanal. Nucl. Chem. 237:125-128.

USEPA. 1996. Record of decision for USDOE Hanford 300-FF-1 and 300FF-5 operable units remedial actions. EPA/ROD/R10-96/143. USEPA, Washington, DC.

Wang, Z., J.M. Zachara, W. Yantasee, P.L. Gassman, C. Liu, and A.G. Joly. 2004. Cryogenic laser induced fluorescence characterization of U(VI) in Hanford vadose zone pore waters. Environ. Sci. Technol. 38:5591-5597.

Williams, J.C. 1999. Historical vadose zone contamination from B, BX, and BY tank farm operations. RPP-5231. Fluor Daniel Northwest, Richland, WA.

Zachara, J.M., C. Liu, J.A. Davis, J.P. McKinley, N. Qafoku, D.M. Wellman, and S. Yabusaki. 2005. Uranium geochemistry in vadose zone and aquifer sediments from the 300 Area uranium plume. PNNL-15121. Pacific Northwest National Laboratory, Richland, WA.

Zachara, J.M., and J.P. McKinley. 1993. Influence of hydrolysis on the sorption of metal cations by smectites: Importance of edge coordination reactions. Aquat. Sci. 55:250-261.

Zielinski, R.A., and A.L. Meier. 1988. The association of uranium with organic matter in Holocene peat: An experimental leaching study. Appl. Geochem. 3:631-643. 